\title{
THE RELATIONS OF RELIGION AND ETHNICITY OF URBAN COMMUNITIES IN SURABAYA
}

\author{
Kunawi Basyir \\ Universitas Islam Negeri Sunan Ampel Surabaya \\ Jl. A. Yani No. 117 Surabaya, Jawa Timur, 60237 \\ e-mail: kunawi@uinsby.ac.id
}

\begin{abstract}
The phenomenon of social life related to religion and ethnicity of urban communities in Surabaya has been and is becoming a special concern for the government of Surabaya and academicians Because, the metropolitan city (Surabaya) which has various types of differences in religion, ethnicity, and culture of ethnic communities (Javanese, Madurese, Chinese, Arabic) has provided its color of in-depth study and research. This article will describe the results of studies and research with the title "religious relations and ethnicity of urban communities in Surabaya" deeply and in detail. This study used a qualitative method, where data collection is held by participant observation and open interviews, then analyzed the data using the social construction theory approach. This research found that religion is no longer a binding tool (unifier) for various ethnic and cultural backgrounds. On the contrary, religion is thought to have been a trigger for the emergence and development of the inter-ethnic conflict.
\end{abstract}

\begin{abstract}
Abstrak: Fenomena kehidupan sosial yang berkaitan dengan agama dan etnis masyarakat perkotaan di Surabaya telah dan menjadi perhatian khusus pemerintah Surabaya dan kalangan akademisi. Karena, kota metropolitan (Surabaya) yang memiliki berbagai jenis perbedaan agama, suku, dan Budaya masyarakat etnis (Jawa, Madura, Tionghoa, Arab) telah memberikan warna tersendiri dalam kajian dan penelitian yang mendalam. Artikel ini akan memaparkan hasil kajian dan penelitian dengan judul "relasi agama dan etnisitas masyarakat perkotaan di Surabaya" secara mendalam dan detail. Penelitian ini menggunakan metode kualitatif, dimana pengumpulan data dilakukan dengan observasi partisipan dan wawancara terbuka, kemudian data dianalisis dengan menggunakan pendekatan teori konstruksi sosial. Penelitian ini menemukan bahwa agama bukan lagi alat pengikat (pemersatu) berbagai latar belakang suku dan budaya. Sebaliknya, agama justru dianggap sebagai pemicu munculnya dan berkembangnya konflik antar etnis.
\end{abstract}

Keywords: religion, ethnicity, social conditions, urban society 


\section{Introduction}

In the millennial era, religious phenomena became a hot issue. That may result in the increase in public knowledge which will lead to a paradigm shift when understanding Islam as a religion. The divergence of religious understanding becomes something that most attracts the attention of academics because religion is always related to human life. The selfish, fanatical, and extreme nature of his religion began to grow and develop in adherents. This is due to the knowledge, culture, and place of residence that determine the pattern of religious practices and behavior. This causes the pattern of the religious life of multicultural ${ }^{1}$ societies will determine the various symptoms because they find each other's identity in social life. ${ }^{2}$

It is interesting to study the detail related to pluralism in Surabaya, because of the diversity has an impact on the various patterns of religious social life that will end up mutually claiming a religious truth and belief. As a nation with a variety of diverse cultures and beliefs, of course, crave justice, order, and harmony both in social life, nation, and state life. Therefore, to realize this certainly requires a healthy interaction between those with different cultural, ethnic, and religious backgrounds. This is not far from the existence of a heterogeneous Surabaya society that would need to be parsed, studied, and analyzed so that it would find a constructive pattern in building community and state life. In turn, it will produce a civilization that is coveted together. Therefore in this study, the author examined the religious relations and ethnicity of urban communities in Surabaya.

As a metropolitan city, Surabaya today witnesses an increase in social and religious turmoil caused by ethnic, socio-cultural diversity developed by various ethnicities (Javanese, Madurese, Chinese, and Arabic). As the second-largest city after Jakarta and the metropolitan city, it is as common in facing problems as other major cities in Indonesia. The basic problem often faced by the government is the population problem. This becomes a separate problem that is immediately resolved, such as the phenomenon of urbanization which has increased significantly every year. This phenomenon was to increase the number of pluralities (differences) by bringing all their respective interests. This condition is a concern for the city government because the economic attraction in Surabaya is the center of attention for the surrounding community.

Based on the phenomena that occur in Surabaya related to socio-religious problems and ethnicity are also no less important when compared to population problems. Both variants often cause new problems in the realm of social life. Observing this, not a few academics began to look to be the object of research because it has its uniqueness for

${ }^{1}$ Robert W. Hefner, Multikulturalisme: Menggugat Realitas Kebangsaan, translated by Bernardus Hidayat (Yogyakarta: Kanisius, 2007), p. 36; Hodri Ariev, Agama dalam Keragaman Etnik di Indonesia (Jakarta: Badan Penelitian dan Pengembangan Agama Departemen Agama, 1998), p. 19.

${ }^{2}$ Afthonul Afif, Identitas Tionghoa Muslim Indonesia: Pergulatan Mencari Jati Diri (Depok: Kepik, 2012), p. 50. 
scientists, especially religious sociologists, where cultural diversity and ethnic presence greatly characterize civilization in it. This multi-ethnic and multi-religious society needs to be revealed through in-depth study through research.

Departing from the pros and cons in addressing the existence of urban society associated with the realization of religion and ethnicity of the many researchers and authors of the book, most of them highlighted political problems and social conflict. ${ }^{3}$ While the study about the relationship between religion and ethnicity in urban communities that relate to social construction has not been found before. So in this gap, the author was tried to explain the results of the research by combining the findings of previous researchers with different study settings. The author observes that Surabaya is a metropolis and the secondlargest city after the capital city of Jakarta with features and nuances of the diversity of religions and ethnicity which colors their daily lives. Thus this study is expected to find new findings that are different from previous findings so that these findings can be used as a reference for local governments to take policies related to the management of religion and ethnicity in the local area.

So that phenomena related to existing themes were easily understood in their entirety, this paper was begun from a discussion of religious issues and ethnicity of urban society in terms of theoretical (text) and dialogue with contextual phenomena then proceed with an analysis of the role of religion in the social construction of urban society which then ends with a closing.

\section{Methodology}

Field studies on the relation of religion and ethnicity of urban communities in Surabaya need to be done naturally, and then the approach used is qualitative (natural paradigm). ${ }^{4}$ This approach is used to be able to see objectively about the socio-cultural and religious life of urban communities in Surabaya. This location was chosen because

\footnotetext{
${ }^{3}$ Abdul Syukur, "Islam, Etnisitas, dan Politik Identitas: Kasus Sunda," in MIQOT: Jurnal Ilmu-Ilmu Keislaman, Vol. XXXV, No. 2, Juli-Desember 2011, p. 407-425. Radosaw Zenderowski, Rafa Wiœniewski, "The Etnic Conflict in the Prosevo Valley the Role of the Ortodox Religion in the Conflict," in Journal Codrul Cosminului, XX, 2014, No. 1, p. 239-258; Saleh Partaonan and Mhd. Syahnan, "The Development of Politico-Religious Sect and its influence on the Writing of History: The Case of Siffin," in Tamaddun, 2002; Jumadi and Mohammad Rizal Yakoop, "Etnisitas sebagai Instrumen Politik dan Keamanan di Kalimantan Barat Pasca Rezim Orde Baru," in Jurnal Ilmu Sosial dan Ilmu Politik, Vol. 17, No. 1, 2013, p. 17-34; Eko Tri Haryanto, "Dinamika Kerukunan Intern Umat Islam dalam Relasi Etnisitas dan Agama di Kalteng," in Analisa: Jurnal of Social Science and Religion, Vol. 20, No. 1, 2013, p. 13-24; Ifansyah Putra, "Agama dan Etnisitas dalam Pemilihan Kepala Daerah di Provinsi Bengkulu 2015," in Al-Imarah: Jurnal Pemerintahan dan Politik Islam, Vo. 2, No. 2, 2017, p. 81-90.

${ }^{4}$ Lexy. J. Moelong, Metode Penelitian Kualitatif (Bandung: Remaja Rosdakarya, 1989), h. 24; Noeng Muhadjir, Metode Penelitian Kualitatif (Yogyakarta: Penerbit Rake Sarasin. 1996), p. 12 .
} 
the pattern of the community is quite plural with various religious, ethnic, linguistic, and cultural backgrounds. Sources of data were obtained through participant observation and in-depth interviews so that researchers gained a deep picture of religious understanding and dogma and their implementation of social life in multi-ethnic and multi-religious societies. Analysis of the data in this study used the analysis of social construction theory initiated by Peter L Berger and Thomas Luckmann. ${ }^{5}$ This analysis was chosen because it is in line with the phenomenon under study that is related to the process of dialectics and negotiations between religion and ethnicity that will lead to the formation of social-culture in the realm of social reality with a variety of different ethnicities, cultures, and religions. After that, it is narrated so that it can provide answers to research problems as a form of conclusions.

\section{Results and Discussion}

\section{Religion and Ethnicity of Urban Communities}

The population of the community in Surabaya is 3,158,943 inhabitants consisting of various tribes, religions, and different cultures. Besides being popularly known as the Hero city, Surabaya is also a business center in the eastern part of Indonesia. The majority of the population is Muslim and followed by Catholics, Protestants, Buddhists, Hindus, and Confucians. ${ }^{6}$ As a metropolitan city, Surabaya has several problems that always arise along with the growth and development of urban civilization culture. In addition to population problems and increasing urbanization rates that are always experiencing significant growth, this will have an impact on the new social order, especially the socio-religious life problems for certain ethnic groups, such as the Javanese, Madurese, Arabic, and Chinese. They have a variety of diversity both in the fields of beliefs, religion, and social culture. Such an existence certainly requires special attention to the local government.

The relation of religion and ethnicity in several major cities in Indonesia including Surabaya has always been a particular concern for academics to be studied and researched. These two variants (religion and ethnicity) are considered the most vulnerable and often lead to friction in religious understanding. Cultural and religious differences are allegedly the main triggers in daily life. Thus, it is natural that studying religious issues needs to juxtapose cultural problems because these two variants always co-exist and influence each other so that followers of religion have different tendencies in responding to them. Such a thing is natural if scientists define religion as a particular, social reality, anthropocentric. ${ }^{7}$

${ }^{5}$ Peter L. Berger and Thomas Luckmann, The Social Construction of Reality: A Treatise in the Sociology of Knowledge (New York: Doubleday, 1966), p. 61.

${ }^{6}$ Team Badan Pusat Statistik, Kota Surabaya Dalam Angka: Surabaya Municipality in Figures 2020 (Surabaya: Badan Pusat Statistik, 2020), p. 31.

${ }^{7}$ Kunawi Basyir, "Makna Eksoteris dan Esoteris Agama dalam Sikap Keberagamaan Eksklusif 
Sociologists and anthropologists say that religion is a cultural system that processes nonempirical forces and is always utilized by every human being as a basis for achieving world safety and safety in the eternal realm later. ${ }^{8}$ The pattern of beliefs and beliefs like this is not only owned by modern society but has been owned by society since humans know civilization (primitive religion). Observing the existence of such a religion, we can illustrate that religion, including Islam, is always dialogue with a culture based on the space and time in which the adherents of the religion are located so that the existence of Islam as a religion has different features such as syncretism, moderate, traditional, puritanical and Sectarian Islam.

This assumption illustrates to us that Islam is not only a revelation but is also the result of the construction of society accompanied by several teachings that come from God and then manifested in the holy book (Al-Qur'an). This is in line with the opinion of M. Amin Abdullah; he stated that religion is a set of ideas of human thought that is implemented in concrete actions in the community by referring to the beliefs and beliefs that are owned by building on their knowledge. Because of the quality of knowledge of each human being is different, it will produce a different understanding and practice of religion. ${ }^{9}$

Thus, when religion is interpreted as absolute truth, it will cause controversy over the truth of the religion itself by claiming each other's truth. It is this atmosphere that usually makes the growth and development of several religious groups or sects such as fundamentalists represented by puritan groups and pluralists represented by moderate and traditionalist groups. Because these two groups have different views when understanding the concept of Islam, then they build each other's mass mobilization in the public sphere, they fight for sympathy in a heterogeneous society.

Patter A. Huff said that fundamentalists are one of the groups who have abandoned present values so that they fail to understand and interpret the nature of religion itself. They tend to be vulgar with an orientation to their intellectual abilities compared to pluralists because they consider the truth of their religion as absolute truth, reject the development of culture in which they live, are not interested in new things (modernization), lack of historical awareness so they don't have critical and dynamic thinking. Huff concluded that they were literalism, primitivism, legalism, and tribalism. Politically they are reactionary populists. ${ }^{10}$ The phrase is in line with was conveyed by Stephen Sulaiman Schwartz who

dan Inklusif," in Teosofi: Jurnal Tasawuf dan Pemikiran Islam, Vol. 8, No. 1, Juni 2018, p. 218; Kunawi Basyir, "The 'Acculturative Islam' As a Type of Home-Grown Islamic Tradition: Religion and Local Culture in Bali," in Journal of Indonesia Islam, Vol. 13, No. 2, 2019, p. 326.

${ }^{8}$ D. Hendropuspito O.C., Sosiologi Agama (Yogyakarta: Kanisius, 1998), p. 34.

${ }^{9}$ M. Amin Abdullah, Studi Agama: Normativitas atau Historisitas? (Yogyakarta: Pustaka Pelajar, 1996), p. 45. Discussion on a broader context see Mhd. Syahnan "Islam as a System: A Critical Analysis of Sayyid Quthb's Principle Thought," in Analytica Islamica, Graduate Program of IAIN Medan, Vol. 4, No. 1, May 2002, p. 45-57. 
argued that pluralist groups are more rational, have a strong enough reasoning power, have philosophical power as a foothold of thinking in studying some of their things using a methodology that is adequate so that the concept of idealism is always progressive along with the development of technology and modernization. ${ }^{11}$

The two camps have been fighting over sympathizers in the public sphere in applying the concept of truth to their respective religions by building a mass base as the strength of their movements. They claim each other a truth that comes from its holy book. ${ }^{12}$ This condition shows the meaning and role of religion in social life is needed as key social control and is one of the footholds of rules, norms, and ethics for the community. In this realm, society has the function and role to explore and implement the meaning and nature of religion itself.

Thus it is fitting for the existence of religion to be able to select the rules and norms that develop in society. The existence of religion has a real meaning, namely as a control of the dynamic growth and development of culture. This is in line with Donovan O. Shaefer's opinion, he revealed that the function of religion is not only as a doctrine that is implemented in the form of ritual, but religion has a more urgent function, namely guarding the existence of norms, ethics, which will form a collective awareness for the wider community. Religion whatever its name has the same task which is to organize conducive and constructive community life. ${ }^{13}$

Because religion has a role as a unifying ethnicity and culture, it is no exaggeration if sociologists view the function of religion as a medium of control over the norms and ethics inherent in society itself. In the era of the industrial revolution 4.0, the Surabaya city has been the opposite. Religion is no longer a means of social control, no longer a means of binding solidarity, but religion has come out of its habitat. This means that religion is believed to be a means of separating one ethnic group from another, all of which are caused by differences in ethnicity, culture, and religion. Such conditions can be felt not only in Surabaya but in other regions in Indonesia, especially since the collapse of the New Order regime. Politically, inter-camps have played in the public sphere by building their respective masses and leading to horizontal conflicts. Here it cannot be denied that religion is also played as the basis of its movement.

${ }^{10}$ Peter A. Huff, "The Challenge of Fundamentalism for Interreligious Dialogue," in Journal JSTOR, Vol. 50, No. 1/2, 2000, p. 98.

${ }^{11}$ Stephen Sulaiman Schwartz, Dua Wajah Islam: Moderatisme vs Fundamentalisme dalam Wacana Global, translated by Hodri Ariev (Jakarta: Blantika \& Tha Wahid Institut, n.d.), p. ix.

${ }^{12}$ Petter Huff, The Challenge of Fundamentalism, h. 12: Kunawi Basyir, "Menimbang Kembali Konsep dan Gerakan Fundamentalisme Islam di Indonesia," in Al-Tahrir: Jurnal Pemikiran Islam, Vol. 14, No. 1, 2014, p. 25.

${ }^{13}$ Donovan O. Schaefer, Religious Affects: Animality, Evolution, and Power (Durham: Duke University Press, 2015), p. 145. 
Therefore contemporary Islamic thinker Abdul Karim Soroush revealed that the existence of modern society is always faced with humanitarian problems related to religion. This problem is not only local but has become a universal problem. The two problems always arise together as time goes by and the place where the religion is embraced. These problems are mainly problems of peace, justice, and human rights. From some of these problems that always bind to religious life in both the East and the West. ${ }^{14}$ Thus Abdullah Na'im has reminded that Muslim communities should be able to understand and capture religion as the basis of the spirit of humanity amid the diversity of beliefs, beliefs, culture, and ethnicity. For Naim, religious diversity for multicultural societies should be understood as a blessing that will create peace based on differences. ${ }^{15}$

Thus to examine religious phenomena related to the ethnicity of urban society in the modern era such as in Surabaya, it can be started through a big theory that was initiated by Emile Durkheim, namely the theory of functionalism. This theory states that every community always cooperatively integrates with an organized system. With this integration, the community will gain equality with productive situations and conditions. Every individual must see that the norms, ethics that apply to society are an inseparable part of life. ${ }^{16}$ This is in line with the message delivered by the Qur'an 49: 13 which means "O people, Verily We created you from a man and a woman and made you nation and tribe so that you know each other. Surely the noblest among you by Allah is the most pious among you. Verily, Allah knows best. ${ }^{17}$

Departing from the description, religion is a social institution built by the community based on mutual integration and based on equality, collective agreements bound by a dogma, symbols, values , and norms that are built-in spirituality. ${ }^{18}$ From this Durkheim concluded that religion is not only an illusion but is an expression of society itself, religion as a binding tool for the growth and development of existing social solidarity. ${ }^{19}$

The thesis is in line with Ronald Robertson's view that each individual in a certain community has their views and differences of belief. Each individual has experience and knowledge that is different from one another. ${ }^{20}$ If it is related between the two views, it

\footnotetext{
${ }^{14}$ Abdolkarim Soroush, Reason, Freedom and Democracy in Islam: Essential Writing of Abdolkarim Soroush (Oxford: Oxford University Press, 2000), p. 63.

${ }^{15}$ 'Abdullahi Ahmed an-Na'im, Islam and the Secular State: Negotiating the Future of Shari'a (New York: n.p., 2008), p. 38.

${ }^{16}$ Emile Durkheim, The Elementary Forms of the Religious Life (London: George Allen \& Unwin, 1947), p. 105.

${ }^{17}$ Departemen Agama RI, Alqur'an dan Terjemahnya (Jakarta: Departemen Agama RI, 1989), p. 840.

${ }^{18}$ Emile Durkheim, The Elementary Forms, p. 106.

${ }^{19}$ Ibid., p. 110.

${ }^{20}$ Roland Robertson, Sosiologi Agama, tr. Paul Rosyadi (Jakarta: Aksara Persada, 1986), p. 76.
} 
certainly can be illustrated that the existence of religion is as an instrument to build a beauty that departs from all differences, both differences in terms of ethnicity, culture, and religion. Because every individual captures religion is very much determined by their knowledge capacity so that from this produces differences in religion and existing beliefs.

Looking at the social reality in Indonesia in the last few years there are significant differences, where religion is no longer a binding that will foster world peace but rather religion brings the darkness of the world. This is indicated by the indication that the conflicts that occurred in parts of the world including Indonesia in recent years are conflicts that are motivated by religious and ethnic differences. Cases of violence and conflict, especially since the end of the New Order rule, political interest did determine but in the subsequent development, religious and ethnic sentiments were involved in it so that the conflict widened everywhere, not only in Surabaya.

This atmosphere has colored our daily lives so that the jargon of civilization is at stake. This atmosphere proves that Karl Marx's thesis is inevitable. Marx stated that religion is merely an illusion or delusion, religion only provides excuses to perpetuate its power so that religion gradually makes the number of oppression of the lower classes of society. For Marx, belief in God was only limited to class struggle. ${ }^{21}$

Associated with the existence of religion in the social sphere often raises some differences in addressing and defining religion itself. Max Weber, for example, he said that religion became one of the spirits for the socio-cultural life of the community. He proved his findings that Protestant ethics can awaken the spirit of social life. He rejected the thesis presented by the previous figure, Karl Marx. Weber said that the conditions and situations of economic life are not always determined by materialistic values but are largely determined by the values that are essential namely religion because only religion has an important role to grow the people's economy. ${ }^{22}$ This kind of thing is in line with Durkheim's thesis which says that religion will have meaning if religion can regulate social life.

Departing from several events of socio-religious problems related to religious relations and ethnicity of urban communities in Surabaya is not much different from big cities in Indonesia such as Bandung, Jakarta, and other big cities. ${ }^{23}$ In Surabaya, for example, it still leaves some issues that have become a challenge for the life of the nation and state in Indonesia. The existence of multicultural societies with various religions and ethnicities

${ }^{21}$ Daniel L. Pals, Seven Theories, p. 139.

${ }^{22}$ Silfia Hanani, Menggali Interelasi Sosiologi dan Agama (Bandung: Humaniora, 2012), p. 27. On the view of the comprehensiveness of religion see Mhd. Syahnan, Contemporary Islamic Legal Discourse (Medan: IAIN Press, 2010), p. 32-34.

${ }^{23}$ N. Daldjoeni, Seluk-Beluk Masyarakat Kota (Pusparagam Sosiologi Kota) (Bandung: Alumni, 1982), p. 45. Soerjono Soekamto, Sosiologi Suatu Pengantar (Jakarta: RajaGrafindo Persada, 2000), p. 45. 
lacks a conducive place. Through both (religion and ethnicity), urban communities identify with each other and make them feel different from one another.

This phenomenon occurs due to the impact of modernization and globalization accompanied by changes in an urban civilization that is so fast. This phenomenon is not accompanied by an awareness of differences so that the existence of exclusive clerics tends to get its stage in a pluralistic society. Such conditions are reasonable if you get resistance to inclusive religionists. The two sides are fighting over each other for the authority of the truth of their respective religions. This is where the plurality of religious life that is tolerant, egalitarian, and civilization for urban communities in the city of Surabaya has been tested for its existence. The motto of Unity in Diversity for the Indonesian people seemed to lose meaning.

The conditions have an impact on the existence of inter-ethnic relations in this Heroes city. Especially for ethnic Chinese and some non-Muslim communities that exist. Based on the observation of researchers that the most ethnic Chinese and some non-Muslim communities feel trauma and fear when meeting and interacting with bearded and veiled Muslim communities. This kind of phenomenon is made possible by the psychological impact caused by the tragedy of suicide bombings in several churches in Surabaya in April 2018. Therefore the problem of religion is something that is most urgent in carrying out daily activities. This is in line with what was conveyed long ago by Samuel P. Huntington, he said that the line of intercultural separation became a very basic means of conflict because cultural relations that are full of tension and religion usually become one of the most dominant distinguishing elements. ${ }^{24}$

To examine the problem of religion and ethnicity in urban communities in Surabaya, it is not enough to just look at the reality, but it needs an in-depth study. Based on observations in which ethnic Chinese, Arabic, Madurese, and Javanese communities have significant social and emotional distances. The data we get is that Chinese ethnic, for example, are reluctant to even have contact with other ethnic groups, namely Arab, Madurese, and Javanese. The strongest allegation is due to ethnic differences and differences in beliefs (religion), although sometimes there is contact between them only limited in the economic field such as in markets, shops, and in certain places.

This phenomenon is in line with one informant of Chinese descent said. He said that they were more comfortable and safe to get along with their ethnic groups (because they were of the same religion). He reasoned that because there was nothing to hide with fellow religions and ethnic groups, they were more comfortable and egalitarian, and there was no racial burden at all. When alluding to issues of association with other ethnicities

\footnotetext{
${ }^{24}$ Samuel P. Huntington, The Clash of Civilizations and the Remaking of World Order (New York: n.p., 2011), p. 60.
} 
and religions, they did not comment. Here we can surmise that they are less familiar and less secure if they interact with other ethnic and religious groups.

This phenomenon is different when there is a dialogue with informants who have similarities about religion and beliefs, even though they are of different ethnicity but feel more secure to mingle and communicate among themselves. Interactions are often in the trade as well as in social and cultural fields. This phenomenon can be found as the relationship between Madurese ethnic communities with Javanese and Arabs in relatively informal forums such as gathering places for young people and the elderly in several villages in the city of Surabaya. They associate and communicate constructively because of similarities in terms of beliefs and religion. Thus, it will then be explained in detail the pattern of religion in constructing social reality and its relation to the existence of ethnic communities in the city of Surabaya.

\section{Religion as a Social Construction of Urban Communities}

From the various definitions of religion, especially those related to social reality as the previous description, it can be narrated that the problem of religion is not just a matter of spiritualism, belief, and divinity (theology), but some issues are more urgent when religion is practiced and live amid heterogeneous society. This will have an impact on the order of people's lives simultaneously. ${ }^{25}$ Therefore to understand the social reality associated with religious life in the city of Surabaya will be analyzed through social construction theory initiated by Peter L. Berger and Thomas Luckmann. He said that society is an objective reality, so to see what the community has to go through several variants, namely: internalization, externalization, and objectification. The three variants essentially run simultaneously and are interrelated with one another.

At the level of objective reality, the existence of society is part of external reality and always faces individuals. But on the other hand, is also accompanied by the habituation (habituation) through other individuals with not just one time, but always repeated so that habituation occurs and finally produces a new pattern and is produced through rational action. This process will then settle and will become a tradition for a social life that will end up being a continuation for the next generation and becoming the legitimacy of the community itself. ${ }^{26}$ The success of the habit of action will succeed if there is an asymmetrical relationship between the objective world, namely society itself, and the subjective world, namely individuals. The failure of socialization is usually determined by the diversity of forms and methods of socialization. Therefore an identity is needed as a key to subjective

\section{${ }^{25}$ Ibid.}

${ }^{26}$ Peter Berger and Thomas Luckmann, The Social Construction of Reality, h. 61. Muhammad Basrowi, Teori Sosial dalam Tiga Paradigma (Surabaya: Yayasan Kampusina, 2004), p. 72. 
reality because that identity has been shaped by social reality. It is formed and nurtured through social dynamics that will take shape and will always be nurtured by society so that it manifests as a collective consciousness. ${ }^{27}$

Thus the theory of social construction will be more urgent if used to dissect the relations of religion and ethnicity associated with the existence of ethnic communities in Surabaya. From there it can be seen as the extent to which religion has a role and can construct buildings of interaction between ethnic groups. Furthermore, religion has a role or not in establishing the presence of multi-ethnic communities in Surabaya.

To understand the extent to which religion has a role in the process of relations between ethnic groups that will produce social institutions that are dynamic and conducive. Then it is necessary to find a basic key that will be able to give a clear picture of the existence of existing phenomena. Thus to dissect the phenomenon researchers try to use the approach of the theory of Social Construction Peter L. Berger and Thomas Luckmann ${ }^{28}$ which states that religion is an idea like a ceiling that is considered sacred and extends to the level of society which peaks at the level of death. Religion for humans can relieve anxiety, anxiety so that every human always tries to build his world through externalization. Humans enlighten themselves based on existing social realities. At this moment, humans will feel enlightened according to their needs and will obtain an objective and realistic form; this is what Burger calls the objectification process. The objective world created by humans will usually be reabsorbed in the internalization process and gradually the objective world can turn into a subjective world. From here Burger provides the following restrictions:

First, he distinguishes between "social facts" and "knowledge". According to him, social facts are something that looks at social reality in the form of association, communication through language which is then manifested in certain groups in the form of social organization. This is where humans will get an inter-subjective experience as a social reality. Whereas "knowledge" is a social reality that is understood and practiced in social life then becomes a reference in social life. Like an NU or Muhammadiyah organization, for example, these two organizations have different rules or teachings both in the field of creed, muamalah, also in the field of Sufism and both have different mass bases.

Second, to see Berger's social relations using the perspectives of "objectivity" and "subjectivity", he combines his theories, Durkheim and Weber. For Burger, the use of objectivity and subjectivity variants is not something that must be separated, but we must use it synthetically so that it can be used to understand all of human life both individually and as a group. Because Berger considers that society is an objective reality that must be understood as a condition that appears and is outside the human self. Furthermore, we must understand

\footnotetext{
${ }^{27}$ Peter L. Berger, et al., Tafsir Sosial Atas Kenyataan: Risalah tentang Sosiologi Pengetahuan, tr. Hasan Basari (Yogyakarta: LP3ES, 1990), p. 40.

${ }^{28}$ Ibid., p. 36.
} 
and realize that it is human beings who shape social reality so objectively the position of humans, in this case, is dealing with society itself.

While the position of society as a subjective reality we should understand that the individuals around the community are difficult to separate because each individual has the role and function of forming the community simultaneously. Vice versa, society has a role and function to form the individuals themselves. So the social reality in this theory is always double between individuals and society. Two intensities cannot be separated because the two variants are always together as an objective and subjective reality.

To combine two different realities, namely between subjective reality and objective reality, Berger uses a three dialectical approach, namely the moment of externalization, internalization, and objectification. ${ }^{29}$ These three moments always run simultaneously. When there is a social process there is certainly something that pulls out of itself and tries to adjust to its environment - the process of externalization. Besides, there is also something that pulls back into itself, meaning that an individual has tried to pull away from the existing social reality and try to get back to himself - adjusting to himself. At this moment an individual seems to be outside - the objectification process. Whereas in the internalization variant where an individual draws from existing social relations and usually they feel that he is a product of society.

In certain societies, for example, we often encounter social institutions built on habituation. In this process, it seems that the actions in society always experience a repetition process when transforming their actions and experiences through communication media in the form of language. Individuals institutionalize their actions as a means of community legitimacy. Thus, researchers try to find out and analyze the social context in the form of social interaction between ethnic groups to further get a clear picture of how the patterns developed by them so that it manifests in a value system that will become a reference to the community itself.

The problem of religious relations and ethnicity is the center of attention for sociologists. Therefore, it is not wrong if Berger makes social interaction as a subject matter in each of his studies because social interaction always involves the relationship of individuals with society at large. Here the individual has a role as an asking subject. $\mathrm{He}$ is a living creature that always runs the activities of daily life. Their actions are nothing but based on meanings that are subjective and have several ways, means, and conditions that surround them to achieve their life goals. Humans are also a complex whole consisting of relations between them that have different patterns from one another.

In the study of social science that the relationship of religion and ethnicity is empowered as a subject matter that has two dimensions, namely the horizontal and vertical dimensions.

\footnotetext{
${ }^{29}$ Muhammad Basrowi, Teori Sosial dalam Tiga Paradigma (Surabaya: Kampusina, 2004),
} p. 72. 
The horizontal dimension does not only mean the meaning of interaction between individuals and individuals but also includes several groups and existing social structures. Therefore the location of religious, economic, cultural, and socio-political factors greatly determines its existence due to social changes that occur in society. This is inseparable from the existing time course, meaning that the past always colors the present and future life so that it cannot be denied if the historical aspect (vertical) becomes important to study. This does not mean eliminating the substance of sociology itself, but sociology is only limited to borrowing historical data to uncover current realities. It is because the existence of the present cannot be separated from the past. From some of the results of the discussion related to the religious relations and ethnicity of urban communities in Surabaya we can describe as follows:

Moment of externalization; Social construction for inclusive communities towards the existence of religion and its implications in the implementation of social interaction between ethnic groups in Surabaya has given us an illustration that community construction (inclusive) to the concept of "religion" will have an impact on some ideas and practices of social interaction between ethnic groups themselves and will lead to the power of religion in shaping the existing social reality. Moment of internalization; At this moment will present an overview of the extent to which the community (exclusive) can construct the existence of religion and have implications for the process of interaction between ethnic groups in Surabaya. From the dialectics, it can be said that the silent majority is exclusive due to the rejection of social reality and has become a collective consciousness (social institutions). This has an impact on the weak ideas and practices of interaction between ethnic groups themselves and it is even possible that there will eventually be an attitude of rejection of the diverse culture and culture of the local community. Furthermore, it will weaken the function and meaning of religion for daily life. From this, it means that religion will lose social control because the strength of religion is weakening.

While at the moment of objectification it can be described that the position and function of society as a social reality is when they understand religious texts about the terms of the interaction between ethnic groups. Normative moments will have an impact on the building of interaction between ethnic groups to be counter literacy. Dialectics at this moment explains that the acceptance of ethnic communities on the existence of religion will have implications for the normative implementation of social interaction between ethnic groups. This normative nature will produce several forms or models of different interactions. The impact caused by this moment will cause a lot of friction when translating the text so that it leads to differences in understanding which then raises some tension between them. Such conditions will easily ignite prolonged conflicts so that the meaning and message of religion as social institutions will be threatened.

Discussing and scrutinizing the results of the analysis above can give an idea that the existence of religion is one of the most crucial facilities in determining the existence 
of multi-ethnic communities such as in the city of Surabaya. This is similar to Emile Durkheim's opinion that religion is a social binding force (between ethnic and interreligious). He further said that religion is a collective consciousness, religion is a social institution. However, based on the analysis of the three variants mentioned above, the objectification variant was ranked first (the strongest), followed by the internalization variant, and the weakest was the externalization variant. This illustrates that the culture and traditions that the community has built for years (collective consciousness) are gradually becoming extinct.

A phenomenon related to the type or form of Islamic urban society in Surabaya at first most of them was Cultural Islam (objectification). However, with the development of modernization and globalization accompanied by a wave of urbanization that increased so sharply that there was a shift from an inclusive Cultural Islam to an exclusive Puritan Islam. At the moment of externalization (moderate groups), they are increasingly displaced. This happens because of the strong exclusive group movement in the vortex of young people with some of their activities on campus and the midst of urban society.

Seeing this condition if it is not anticipated early on, religion will gradually lose meaning in the lives of urban Surabaya people because religion is no longer a binding tool that unites various ethnic groups as thesis Emile Durkheim ${ }^{30}$ and Max Weber. ${ }^{31}$ Based on the analysis that the internalization and objectification variants are very dominant. This means that the conditions of religious social life will be easily ignited with racial issues and lead to conflicts between ethnic and interfaith groups.

Apart from differences in interaction, many other variables, such as justice and economic issues are influenced. Likewise, the development of knowledge and technology is no less important in determining the dynamics of ethnic and religious development. It is suspected that the growth and development of the Islamic community that is incorporated in exclusive Islamic (Salafi) network groups which are more radical tends to increase. Such conditions will easily ignite political dynamics based on religion. As an example of the development of religious-political ideology represented by fundamentalist groups and Islamic politics represented by pluralist Islamic groups. Both sides are always fighting for sympathy in the public sphere. The power of political Islam mobilization in Surabaya is increasingly experiencing significant growth. This group movement can be expected to have an impact on the decline in the number of religious plurality which in turn will have an impact on the weakening of the civilization of urban society because religion no longer has any meaning in social life. Religion is no longer a binding agent of unity, but rather religion will make the atmosphere less conducive. This condition is in line with the opinion of Yumadi and Muhammad Rizal Yakoop that political change after the New Order has undergone a drastic change, where ethnic and religious issues are the issues

\footnotetext{
${ }^{30}$ Emile Durkheim, The Elementary Forms, p. 124.

${ }^{31}$ Silfia Hanani, Menggali Interelasi Sosiologi, p. 30.
} 
that determine the occurrence of conflicts everywhere including in West Kalimantan. ${ }^{32}$ Based on observations and in-depth analysis, it illustrates that the issues of religion and ethnicity remain a particular concern for urban communities in Surabaya.

\section{Conclusion}

From the presentation and analysis of the discussion above, it can be concluded that the phenomenon of religion and ethnicity in urban communities in Surabaya is quite problematic. The problem of socio-religious life in the future is thought to be less indicative of a conducive situation even though so far there has not been any meaningful conflict. However, it can be illustrated that the relationship between religion and ethnicity does not show a mutualistic relationship. This happens due to differences in beliefs and cultures for ethnic community groups and the lack of conducive interaction. This is inevitable because of the growth and development of young people, especially the middle-class community who are members of an exclusive (Salafi) group that is anti-local traditions and modernization. Various activities and movements through studies of diversity (halaqah) and social activities in an urban society increasingly lively. Observing such conditions certainly requires strategic steps for all elements of government, religious leaders, community leaders, and academics to take part and find a solution that is right and can minimize the growth and development of their movements so that religion will reap the true meaning of as a means of unifying ethnic groups in Surabaya.

\section{References}

Abdullah, M. Amin. Studi Agama: Normativitas atau Historisitas?. Yogyakarta: Pustaka Pelajar, 1996.

Afif, Afthonul. Identitas Tionghoa Muslim Indonesia: Pergulatan Mencari Jati Diri. Depok: Kepik. 2012.

An-Naim, Abdullahi Ahmed. Islam, and the Secular State: Negotiating the Future of Shari'a. New York: n.p., 2008.

Ariev, Hodri. Agama dalam Keragaman Etnik di Indonesia. Jakarta: Badan Penelitian dan Pengembangan Agama Departemen Agama RI., 1998.

Basrowi, Muhammad. Teori Sosial dalam Tiga Paradigma. Surabaya: Yayasan Kampusina, 2004.

Basyir, Kunawi. "Makna Eksoteris dan Esoteris Agama dalam Sikap Keberagamaan Eksklusif dan Inklusif," in Teosofi: Jurnal Tasawuf dan Pemikiran Islam, Vo. 8, No. 1, Juni, 2018.

${ }^{32}$ Jumadi and Yakoop, "Etnisitas sebagai Instrumen Politik, p. 17. 
Basyir, Kunawi. "Menimbang Kembali Konsep dan Gerakan Fundamentalisme Islam di Indonesia," in Al-Tahrir: Jurnal Pemikiran Islam, Vol. 14, No. 1, 2014.

Basyir, Kunawi. "The 'Acculturative Islam' As a Type of Home-Grown Islamis Tradition: Religion and Local Culture in Bali," in Journal of Indonesia Islam, Vol. 13, No. 02, 2019.

Berger, Peter L. and Thomas Luskmann. The Social Construction of Reality: A Treatise in the Sociology of Knowledge. New York: Doubleday, 1966.

Berger, Peter L., Frans M Parera \& Thomas Lukcmann. Tafsir Sosial Atas Kenyataan: Risalah tentang Sosiologi Pengetahuan, translated by Hasan Basari. Yogyakarta: LP3ES, 1990.

Daldyoeni, N. Seluk-Beluk Masyarakat Kota (Pusparagam Sosiologi Kota). Bandung: Alumni, 1982.

Departemen Agama RI. Alqur'an dan Terjemahnya. Jakarta: Departemen Agama RI, 1989.

Durkheim, Email. The Elementary Forms of the Religious Life. London: George Allen \& Unwin, 1947.

Hanani, Silfia. Menggali Interelasi Sosiologi dan Agama. Bandung: Humaniora, 2012.

Huff, Peter A. "The Challenge of Fundamentalism for Interreligious Dialogue," in Journal YSTOR, Vol. 50, No. 1, 2000.

Liliweri, Alo. Makna Budaya dalam Komunikasi Antar Budaya. Yogyakarta: LKiS, 2003.

Moelong, Lexy Y. Metode Penelitian Kualitatif. Bandung: Remaja Rosdakarya, 1989.

Muhajir, Noeng. Metode Penelitian Kualitatif. Yogyakarta: Rake Sarasin. 1996.

O. Schaefer, Donovan. Religious Affects: Animality, Evolution, and Power. Durham: Duke University Press, 2015.

O.S, D. Hendropuspito. Sosiologi Agama. Yogyakarta: Kanisius, 1998.

P. Huntington, Samuel. The Clash of Civilizations and the Remaking of World Order. New York: tt, 2011.

Partaonan, Saleh, and Syahnan, Mhd. "The Development of Politico-Religious Sect and its influence on the Writing of History: The Case of Siffin," in Tamaddun, 2002.

Putra, Ifansyah. "Agama dan Etnisitas dalam Pemilihan Kepala Daerah di Provinsi Bengkulu 2015," in Al-Imarah: Jurnal Pemerintahan dan Politik Islam, Vo. 2, No. 2, 2017.

Robertson, Roland. Sosiologi Agama, tr. Paul Rosyadi. Jakarta: Aksara Persada, 1986.

Schefer, Rishard T. Sociology: A Brief Introduction. New York: Ms. Graw-Hill, 1989.

Schwartz, Stephen Sulaiman. Dua Wajah Islam: Moderatisme vs Fundamentalisme dalam Wacana Global, tr. Hodri Ariev. Jakarta: Blantika \& The Wahid Institut, n.d.

Soekamto, Soerjono. Sosiologi Suatu Pengantar. Jakarta: RajaGrafindo Persada, 2000.

Soroush, Abdolkarim. Reason, Freedom, and Democracy in Islam: Essential Writing of Abdolkarim Soroush. Oxford: Oxford University Press, 2000.

Suyanto, Bagong. Anatomi dan Perkembangan Teori Sosial. Yogyakarta: Aditya Media Publissing, 2010. 
Syahnan, Mhd. "Islam as a System: A Critical Analysis of Sayyid Quthb's Principle Thought," in Analytica Islamica, Vol. 4, No. 1, May 2002.

Syahnan, Mhd. Contemporary Islamc Legal Discourse. Medan: IAIN Press, 2010.

Syam, Nur. Tantangan Multikulturalisme di Indonesia. Yogyakarta: Kanisius, 2009.

Syukur, Abdul. "Islam, Etnisitas, dan Politik Identitas: Kasus Sunda," in MIQOT, Vol. XXXV, No. 2, Juli-Desember 2011.

Team Badan Pusat Statistik. Kota Surabaya dalam Angka: Surabaya Munisipality in Figures 2020. Surabaya: Badan Pusat Statistik, 2020.

Tri Haryanto, Eko. "Dinamika Kerukunan Intern Umat Islam dalam Relasi Etnisitas dan Agama di Kalteng," in Analisa: Jurnal of Sosial Sciense and Religion, Vol. 20, No. 1, 2013.

Yumadi \& Mohammad Rizal Yakoop. "Etnisitas sebagai Instrumen Politik dan Keamanan di Kalimantan Barat Pasca Rezim Orde Baru," in Jurnal Ilmu Sosial dan Ilmu Politik, Vol. 17, No. 1, 2013.

Zenderowski, Radoslaw., Rafa Wiœniewski. "The Ethnic Conflict in the Presevo Valley: The Role of The Orthodox Religion in the Conflict," in Journal Codrul Cosminului, XX, 2014. 